\title{
The End Is Nigh, and the Work Has Just Begun
}

\author{
Richard Jones
}

$\mathrm{T}$ his will be my last report as a Presidential Officer of CSHP, as our new President Elect will be assuming responsibility for the Internal Liaison portfolio at the Annual General Meeting during the Summer Educational Sessions (SES 2010) in August. So I find myself asking where three and a half years have gone, and what we-Council and members of CSHPhave accomplished in this time.

I think we can be very proud of the significant advances we have made with our advocacy activities across the country. In this, we are supported by initiatives such as CSHP 2015 and the Blueprint for Pharmacy. These efforts are achieving legislative changes related to pharmacists' scope of practice, which will enable better use of pharmacists' skills and ultimately will improve patients' access to services within the health care system.

For the first time in the history of the CSHP, we are completely rewriting the Society's bylaws. This work entails a substantial consultative effort involving the branch delegates and presidents. The new bylaws will more effectively and formally solidify the relationships of the Society with its branches and their chapters. The new bylaws will also redefine the relationship of the Society with its affiliated boards. This work is well on its way to completion and the new bylaws are expected to be presented to the members for endorsement at SES 2011.

CSHP has been invited to name representatives to work with various of our partner healthcare organizations. This has enabled our Society to foster meaningful relationships with these groups and has provided many opportunities for collaboration. This has in turn significantly benefited the entire patient care team delivering health care services and, more specifically, CSHP members in hospital practice.

These are but a few of the major developments in which I have had the pleasure of participating on your behalf as an executive officer. However, there is another aspect of this role that has been absolutely overwhelming, one that forms my lasting impression of our Society. It is also why I feel so privileged to have had your trust and respect in serving as a Presidential Officer. I have been extremely impressed by the immense number of members who

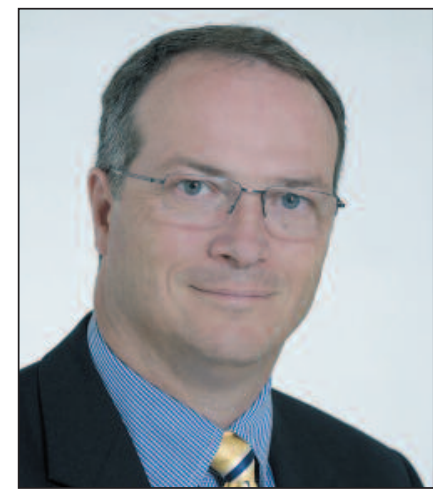
freely apply their talents and experience, thereby contributing to an unbelievably strong base of volunteerism and success for our profession and this Society. Of course, we also have a great supporting team in the CSHP office, representing the glue holding all of our efforts together. I have been truly humbled by this opportunity to serve in such an important role in our Society. I am also very proud to have been one of the many volunteers to work with all of you toward optimizing patient care and advancing pharmacy practice through CSHP.

As my term as a member of the CSHP Executive draws to a close, a chapter is ending, but the work of our Society on these and other issues near and dear to us continues. Now is the time to step up our game and to fully realize the value we can bring to patients' health care.

In closing, I would like to share a quote from a very good friend whom I admire greatly: "Be a giver, not a taker; expect nothing in return but friendship." Thank you for the great privilege of serving you.

Richard Jones, RPh, BSC, BSP, is Past President and Internal Liaison for the CSHP. 